\title{
Bowling Green State University ScholarWorks@BGSU
}

8-2018

\section{Exit, Voice, and Public Reason}

Kevin Vallier
Bowling Green State University, kvallie@bgsu.edu

Follow this and additional works at: https://scholarworks.bgsu.edu/philosophy_pub

Part of the Philosophy Commons, and the Political Science Commons

How does access to this work benefit you? Let us know!

\section{Repository Citation}

Vallier, Kevin, "Exit, Voice, and Public Reason" (2018). Philosophy Faculty Publications. 1.

https://scholarworks.bgsu.edu/philosophy_pub/1

This Article is brought to you for free and open access by the Philosophy at ScholarWorks@BGSU. It has been accepted for inclusion in Philosophy Faculty Publications by an authorized administrator of ScholarWorks@BGSU. 


\section{Exit, Voice, and Public Reason}

The theories of deliberative democracy and public reason liberalism are tightly connected. Theorists in both camps hold that political institutions are legitimate when they are based on the reason of the public. Deliberative democrats specify this condition by claiming that legitimate institutions make decisions based on open, equal, democratic discussion among citizens in the public square. Public reason liberals hold that legitimate institutions are those that can be justified to multiple reasonable points of view, that is, to the public as a whole. Many theorists regard the two theoretical traditions as roughly equivalent because they equate public deliberation with the idea of public justification; the idea of public justification in public reason liberalism is understood as a series of public, deliberative acts aimed at justifying certain laws and public policies.

But public justification and public deliberation are distinct ideas. Public justification is a social state where each person has sufficient moral reason to endorse the political power and legal order to which she is subject; public deliberation is simply one method of reaching that social state. Once we grasp the distinction between the justification relation and the social processes by which this relation is established, we can see that social processes other than deliberation may play an important role in achieving public justification.

In this paper, I distinguish between methods of reaching public justification and argue that public reason liberals should appeal to social exit as a supplement to democratic deliberation. As Albert O. Hirschman (1969) taught us long ago, social change can occur through voice, where persons openly express concerns and demand institutional change, or through exit, where persons leave institutions that they dislike or disagree with. 
Both mechanisms create incentives for institutional change, and so both mechanisms can be used to align the legal order with what is publicly justified for citizens. But as Hirschman noted, voice and exit mechanisms can limit the effectiveness of the other in bringing about social change. Thus, voice and exit mechanisms must be carefully balanced in establishing a publicly justified polity.

Introducing exit into public reason greatly alters how public reason liberals should understand their view as well as how they should address institutional problems. They have focused exclusively on how to use deliberation to establish a publicly justified polity. If exit can also yield public justification, normative and social scientific inquiry within public reason liberalism should shift dramatically, with balanced investment in exploring the promise of voice and exit. ${ }^{1}$ Even the modest thesis that exit can be an effective supplement to voice is highly consequential for the dominant branch of liberal political theory. A second contribution of this essay is to situate public reason views within the turn to exit in political theory found in contemporary republican (Taylor 2017) and classical liberal (Somin 2016) theorizing; many political theories should pay more attention to exit.

I explore exit through political decentralization, especially federalist arrangements. By decentralizing legal authority to states or localities and allowing persons to move freely between them, citizens can find legal regimes closer to what they have most reason to

\footnotetext{
${ }^{1}$ For instance, we can now see the benefits of employing models of exit behavior to determine what can be publicly justified, such as Tiebout (1956) sorting model, which predicts the policy implications of movement between localities.
} 
accept. $^{2}$ This self-sorting process not only moves people to legal orders they prefer, but pressures smaller political bodies to alter their laws to attract citizens, such as changing tax rates or eligibility for social services.

I'll sketch these ideas in five further sections in the hopes of pointing towards avenues for further research.

Public Justification and Public Deliberation

As noted, public reason liberals say that political power must be subject to a multilateral justification in order to be legitimate. Political power must be acceptable to multiple reasonable points of view in a society suffused with incompatible views about what the good and justice require (Rawls 2005, 136). Thus, a political order is only legitimate when its coercive governmental apparatus is endorsed by the reason of each member of the public. Public reason liberals have many internal disagreements, but most think public reason implies principles of justification and principles of deliberation. Principles of justification specify when political power is justified for each member of the public, whereas principles of deliberation require citizens to engage in the deliberative act of attempting to justify their preferred principles to one another (395). But the relationship between justification and deliberation has often gone unexplored.

\footnotetext{
${ }^{2}$ I apply public justification to individual laws, with Quong 2011, pp. 273-87 and Gaus 2011, pp. 490-7, though this assumption is not necessary to vindicate my thesis.
} 
As I understand the idea of public reason, it is foremost a justificatory principle; it determines when political coercion is justified for each person. This means that deliberative principles can be grounded in justificatory principles in three steps: (i) establish an appropriate conception of public justification, (ii) demarcate the set of justificatory reasons - the reasons that can justify coercion — and (iii) argue that a deliberative practice will ensure that genuine justificatory reasons largely determine the shape of the law. Only successful arguments for each step can connect justification and deliberation. This insight is easily missed. Again, some public reason liberals think public justification immediately entails or is to be identified with deliberative behavior (Cohen 1989, 21).

Assuming deliberative principles can be justified, they usually take the form of doctrines of restraint, since these principles morally require citizens to restrain themselves from offering and acting upon certain kinds of reasons in political life. Restraint typically requires that the reasons we offer and act upon in politics be shared, shareable, or accessible reasons (Vallier 2018). John Rawls (2005, 450) argues that citizens only reason publicly when they deliberate "within a framework of what he or she sincerely regards as the most reasonable political conception of justice." Amy Gutmann and Dennis Thompson $(1996,55)$ argue that, in a deliberative democracy, citizens are duty-bound to only use reasons that "can be shared by fellow citizens who are similarly motivated." Micah Schwartzman $(2011,378)$ argues that justifications are public only when they are "based on reasons drawn from a family of shared moral and political values."

Gerald Gaus (2011, 41) and I (Vallier 2014) allow unshared and inaccessible reasons into the set of justificatory reasons. We also reject deliberative principles while 
retaining justificatory principles, so some public reason liberals, at least the "convergence" theorists, stress the deliberation-justification distinction.

Justificatory and deliberative principles are separated by considerable logical space; and the arguments that can bridge this space are seldom provided in the literature. So it is unclear the extent to which deliberative principles can, by themselves, establish public justification. Fortunately, exit can help.

Voice and Exit

Hirschman identified exit and voice as two approaches to organizational reform. Organization members who wish to change the decisions and structure of their organization can exercise power either by leaving the organization or by communicating concerns and proposing improvements. Consumers exercise exit when they stop buying a company's product; they exercise voice when they complain to the producer. Employees exercise exit when they quit and find another job; they exercise voice when they appeal to a union to generate better working conditions. Citizens exercise exit when they emigrate; they exercise voice when they vote.

Exit and voice have different advantages. Voice communicates more information and gives constituents ongoing political power. Exit can often be more effective, however, given that the organization member is no longer present and so no longer subject to the organization's flaws. Further, losing a member is often a greater cost to an organization than addressing her complaints. Voice and exit also impact one another's effectiveness. Voice can forestall exit by giving the organization member more ways to express her 
dissatisfaction. Exit can discourage voice by removing the voice of those who exit, as well as discouraging those who would expend the effort to use voice to improve their organization. If persons can cheaply exit institutions, the relative costs of using voice increase; moreover, watching others exit may lead deliberators to become despondent and inactive.

Exit and voice mechanisms are both relevant for determining the content of the law.

Citizens can use voice to change the law, or they can respond to laws they dislike by leaving or no longer participating in their political institutions. Public reason liberals have overlooked the fact that exit can move the law into closer alignment with what is publicly justified. If laws are justified for each reasonable point of view, we can expect some degree of satisfaction and stability from the citizenry; but unjustified laws are often seen as immoral, unjust, and illegitimate, and so will create dissatisfaction. Dissatisfaction can be expressed and ameliorated by exit. Political officials who want to keep their citizens around will change the law to meet citizens' needs, at least when officials must compete with the officials of other polities or provinces.

That said, citizens are sometimes mistaken about what they have reason to do and sometimes fail to act on the reasons they have. Consequently, exit mechanisms may conform a polity's laws to what citizens want, not what is justified for them. This means we must eventually establish a correlation between citizens' justificatory reasons and the reasons they act upon.

Establishing the correlation would require considerable empirical work that I lack the ability to conduct. But consider three points. First, this paper advances the thesis that exit mechanisms can supplement voice. Vindicating my thesis therefore only requires that 
exit can improve the justifiability of the laws to which citizens are subject, and this in turn only requires that citizens tend to act on the justificatory reasons they have. The assumption that citizens tend to act on the reasons they have is prima facie plausible, and is taken for granted by deliberative democrats. Second, we should not single out exit mechanisms for failing to match citizens' exit choices with their justificatory reasons when voice mechanisms raise the same concern. After all, citizens can voice irrational and vicious opinions, offering bad deliberative inputs. And political officials can fail to provide justifiable laws even in response to good deliberative inputs. Thus, public deliberation faces a similar concern as social exit. Third, we don't need to decide between voice and exit; a publicly justified polity should appeal to a mix of the two. While finding the optimal mix is difficult, there is no reason to think that we should drop exit and use voice alone. We should be able to find cases where exit is an effective supplement.

Deliberativists often argue that deliberation can change pre-reflective preferences in order to produce more consensus and more reasoned political decisions (Bohman and Rehg 1998, ix-xvii). Thus, deliberation helps to generate more publicly justified policies by changing people's real views and bringing them in line with which reasons truly apply to them. Moreover, political decisions will become more sensitive to these reasons uncovered by further deliberation. A deliberativist might object, therefore, that exit is not a transformative process because exiters keep their pre-reflective preferences and find institutions that suit those pre-reflective preferences.

In one way, pre-reflective sorting is not a problem for exit mechanisms, since a major motivation for emphasizing deliberation is to ensure that a diverse public can reach a certain degree of consensus on political issues in order to ensure that the resulting policies 
track the reason of the public. But if exit is available as well as voice, there is less need to resolve many disputes by consensus since people can form new sub-publics with high degrees of consensus, such as federative units. This weakens the need to transform preferences. And if preference transformation is necessary, exit processes often involve processes of reflection that can be transformative as a person weighs various considerations in deciding whether to exit one legal regime and enter another.

\section{Exit, Decentralization, and Federations}

I will now illustrate my thesis by exploring federalism as an attractive exit mechanism.

Federalism is a kind of political decentralization. We can understand decentralization as involving the vertical division of the powers of government between federal, state, and local levels. Decentralization is therefore similar to Andreas Føllesdal's (2014) understanding of federalism, which affirms "divided powers between member units and common institutions." In a federalist model, sovereignty "is non-centralized, often constitutionally, between at least two levels so that units at each level have final authority and can be self-governing in some issue area." As Ronald Watts (1998, 120) notes, decentralized political orders are "the genus of political organization that is marked by the combination of shared rule and self-rule," that is, the national with the local.

There are several types of political decentralization, such as unions, confederations, leagues, and hybrids; a federation involves a "territorial division of power between constituent units-sometimes called 'provinces', 'cantons', possibly 'cities', or confusingly 'states'-and a common government” (Føllesdal 2014). Federative 
constitutions typically specify the relevant arrangements and the authorities of both levels are usually directly elected (Watts 1998,121 ). In contrast, confederations tend to have a weaker center, as they might allow member units to legally exit, only exercise authority delegated by member units, or subject the institutional center to vetoes.

Here I will focus on reasons to have federations as an alternative to highly centralized states. We can further specify federalism as allowing small, local units to have consequentially unique policies and that people and goods can use low cost transportation to move between them. Taxation and spending are also linked at each governance level, a kind of fiscal federalism (Oates 1999).

Several considerations favor federal arrangements: (i) better protections for unpopular ethnic, regional, or political groups, (ii) accommodations for minority groups whose political dissatisfaction would otherwise lead to violent separation, and (iii) encouragement for citizens with similar policy preferences to cluster, providing more policy satisfaction (Føllesdal 2014, 3.2).

Finally, (iv), federations encourage rational reflection in deciding which laws should apply to each person. Deliberative norms will encourage citizens to be reflective about which policies to support within a single polity. However, citizens seldom have a causally significant impact on policy outcomes, and so their incentive to deliberate well is weakened. Citizens may be rationally ignorant (Downs 1957) of political knowledge required for effective political decision-making and deliberation. Exit deliberation should function rather differently. Each person decides whether to exit and her exit-choice will have a considerable causal impact on which laws affect her. She therefore has an incentive to deliberate more carefully about relocating than voting. After all, most people deliberate 
more about which house to buy than which politician to support. Exit can therefore increase the degree to which legal policy formation is based on good reasoning since the law will sometimes be responsive to the exit choices of citizens. Now, again, these two types of deliberation are different. Voice-deliberation occurs with others, whereas exit-deliberation usually occurs within a single mind or small group. Yet exit-deliberation can still conform the law to what is justified for each person, perhaps moreso than public deliberation, based on the differing incentives for rational reflection for voice and exit.

Federal structures should therefore prove critical for matching the legal order to what is publicly justified. In many cases, there is simply too much diversity at the national level to solve political problems, or to hope that deliberation will yield agreement. Effective solutions to these pressing issues might be unjustifiable at the national level, but could be solved at lower levels of government, where there is less diversity and disagreement. This is because states and provinces often have more unified political cultures and so can be expected to come to consensus, or something near enough, when a national government cannot. Federations thereby become appropriate when a political decision is necessary but where no solution can be justified at the national level. Second, as noted, federations can provide incentivize good deliberation and reasoned decision-making since people will sometimes make more rational exit-decisions than voice-decisions.

\section{Objections to Federative Decentralization}

I will now address six objections to using federations in public reason. 
(1) In the United States, the language of states' rights has often served to legitimize the mistreatment of black Americans; so American federalism might be a bad idea. Of course, historical injustices against black Americans will not demonstrate the inadequacy of federalism in states without this legacy. But even in America worries about discrimination at more local levels only provide reason to avoid decentralization on racial policy and related issues, perhaps such as higher education, healthcare, pensions, real estate, civil rights, and so on. Unconnected issues can still have a federalist solution.

(2) Federations raise a minority-within-a-minority problem. ${ }^{3}$ Were the US federal government to hand decisions down to Texas, liberal cities like Austin would find policy less to their liking, and Illinois outside of Chicago might find public policy skews further left than they find acceptable. Federation-style decentralization can therefore undermine public justification if it produces regimes that establish public justification for a smaller proportion of persons than the proportion found in the larger governing body. We can sometimes address the minority-within-a-minority problem with further decentralization. Work on polycentric legal arrangements (Jacobs 1992; Ostrom 1990) shows that decentralized social institutions can often produce efficient solutions to social problems. ${ }^{4}$ Local groups sometimes provide creative, novel solutions to these problems as well.

(3) Hirschman $(1969,43)$ argued "The presence of the exit alternative can therefore tend to atrophy the development of the art of voice." So one danger of appealing to exit is

\footnotetext{
3 Thomas Christiano (2010, 288-99) addresses a similar minority-within-a-minority problem.

${ }^{4}$ Brian Kogelmann (2017) links public reason to polycentric arrangements.
} 
that exit will make voice less effective. Institutions will have fewer incentives to change if their most articulate and committed citizens exit the polity. Institutions will rot as their quality degrades. However, we must balance the benefits of developed voice with the potential benefits of developed exit. The fact that exit mechanisms may decrease the art and exercise of voice is a cost, but if exit mechanisms more than compensate for this cost, then expanding exit is still worthwhile. And exit might surprise us by encouraging majorities to listen to exiting minorities, as well as inspiring émigrés to participate in deliberation given their greater satisfaction with their new political unit.

(4) Competition between political units may create a race to the bottom, with polities changing laws and policies in ways that make the laws and policies less justified for their members, especially those who lack the resources to leave their political orders. These issues also arise in economic competition between nation-states (Dietsch 2015). A race to the bottom is a real risk, but it has to be weighed against the hope of a race to the top. Exit can trigger a reduction in justified policies, but it can also trigger an increase in justified policies.

The race to the bottom might beat the race to the top because richer and more influential citizens are more able to exercise exit, and so polities will offer policies that favor these citizens over poorer, less influential citizens. But, first, rich and influential citizens don't always or even usually vote purely in their self-interest. Many favor egalitarian and progressive policies, and their sense of justice will still operate in a world with more exit than we currently have. Second, the poor can still exit, even if exit is sometimes expensive, and states can adopt policies that reduce exit costs for the poor, say by providing moving incentives to poor citizens of other polities, like health-insurance 
portability or relocation vouchers. So polities may often feel competition to become more social democratic rather than less. Third, the overwhelming majority of global migrants are from the poorest and most vulnerable groups, and so have a strong incentive to use exit rights, whereas wealthier people face a weaker incentive to take the costly step of exiting their political institutions. Fourth, even our exit-limited democracy must grapple with politically powerful citizens misusing their influence, so the difference between exitfriendly democracy and exit-limited democracy is only a matter of degree.

(5) Citizens might only exit (i) if local units have distinct policies, (ii) some policies better match what is publicly justified for them, and (iii) citizens can determine whether (i) and (ii) hold. Conditions (i)-(iii) are hard to meet, perhaps limiting the attraction of exit. But federalist policy markets should yield pre-emptive policy changes so long as the marginal émigré is prepared to exit. Local units may respond by advertising and offering new policies and helping citizens relocate, much as firms respond to the marginal buyer. Also, similar difficulties hamper deliberation, but this is a reason to encourage voice, not limit it. The same goes for exit.

(6) Exit mechanisms may vary in their capacity to satisfy different conceptions of justificatory reasons. One could argue, for instance, that exit will encourage a person to find laws that conform to her private, convergent reasons, but not to the reasons she shares with others. Citizens are, after all, more likely to make personal decisions about where to live based on private factors, including comprehensive reasons, whereas in democratic deliberation they may be more likely to express themselves in terms of shared reasons. So exit could be friendly to convergence approaches to public justification, but hostile to the dominant consensus approaches. Even so, the consensus model might also be bolstered by 
exit. If people self-sort into polities where others share their values, the polity will have more shared reasons, and so using shared reasons in politics will be easier and less burdensome. That means consensus politics may actually be improved, since each federal unit will track the consensus standard more closely for their citizens, even if there is more variation between federal units. For this reason, I do not think the case for exit mechanisms depends on adopting a particular conception of justificatory reasons.

\title{
Conclusion
}

Exit mechanisms like federalism can supplement voice in creating a publicly justified legal order and so deserve the enthusiasm that public reason liberals place in public deliberation. We should eagerly explore multiple methods of establishing a publicly justified polity.

\author{
Works Cited
}

Bohman, James, and William Rehg, eds. 1998. Deliberative Democracy: Essays on Reason and Politics. New York: MIT Press.

Christiano, Thomas. 2010. The Constitution of Equality: Democratic Authority and Its Limits. New York: Oxford University Press.

Cohen, Joshua. 1989. Deliberation and Democratic Legitimacy. In The Good Polity: Normative Analysis of the State, edited by Alan Hamlin and Philip Pettit, 17-34. Oxford: Blackwell.

Dietsch, Peter. 2015. Catching Capital: The Ethics of Tax Competition. New York: Oxford University Press.

Downs, Anthony. 1957. An Economic Theory of Democracy. New York: Harper.

Føllesdal, Andreas. 2014. Federalism. Stanford Encyclopedia of Philosophy, http://plato.stanford.edu/entries/federalism. Accessed August 12018.

Gaus, Gerald. 2011. The Order of Public Reason. New York: Cambridge University Press. 
Gutmann, Amy, and Dennis Thompson. 1996. Democracy and Disagreement. Cambridge: Belknap Press of Harvard University Press.

Hirschman, Albert. 1969. Exit, Voice, and Loyalty. Cambridge: Harvard University Press. Jacobs, Jane. 1992. The Death and Life of Great American Cities. New York: Random House.

Kogelmann, Brian. 2017. Justice, Diversity, and the Well-Ordered Society. Philosophical Quarterly, 67, 663-684.

Oates, Wallace. 1999. An Essay on Fiscal Federalism. Journal of Economic Literature 37, 1120-1149.

Ostrom, Elinor. 1990. Governing the Commons: The Evolution of Institutions for Collective Action. Cambridge: Cambridge University Press.

Quong, Jonathan. 2011. Liberalism without Perfection. New York: Oxford University Press.

Rawls, John. 2005. Political Liberalism. 2nd ed. New York: Columbia University Press.

Schwartzman, M. 2011. The Sincerity of Public Reason. Journal of Political Philosophy 19, 375-398.

Somin, Ilya. 2016. Democracy and Political Ignorance: Why Smaller Government Is Smarter ( $2^{\text {nd }}$ edition). Palo Alto: Stanford University Press.

Taylor, Robert. 2017. Exit Left: Markets and Mobility in Republican Thought. New York: Oxford University Press.

Tiebout, Charles. 1956. A Pure Theory of Legal Expenditures. Journal of Political Economy 64, 416-424.

Vallier, Kevin. 2014. Liberal Politics and Public Faith: Beyond Separation. New York. Routledge.

-----. 2018. Public Justification. Stanford Encyclopedia of Philosophy, http://plato.stanford.edu/entries/justification-public/. Accessed August 12018.

Watts, Ronald. 1998. Federalism, Federal Political Systems, and Federations. Annual Review of Political Science 1, 117-137. 